\title{
Presence of Helicobacter spp. DNA in the gallbladder of Egyptian patients with gallstone diseases
}

A. Ghazal, ${ }^{1}$ N. El Sabbagh ${ }^{2}$ and M. El Riwini ${ }^{3}$

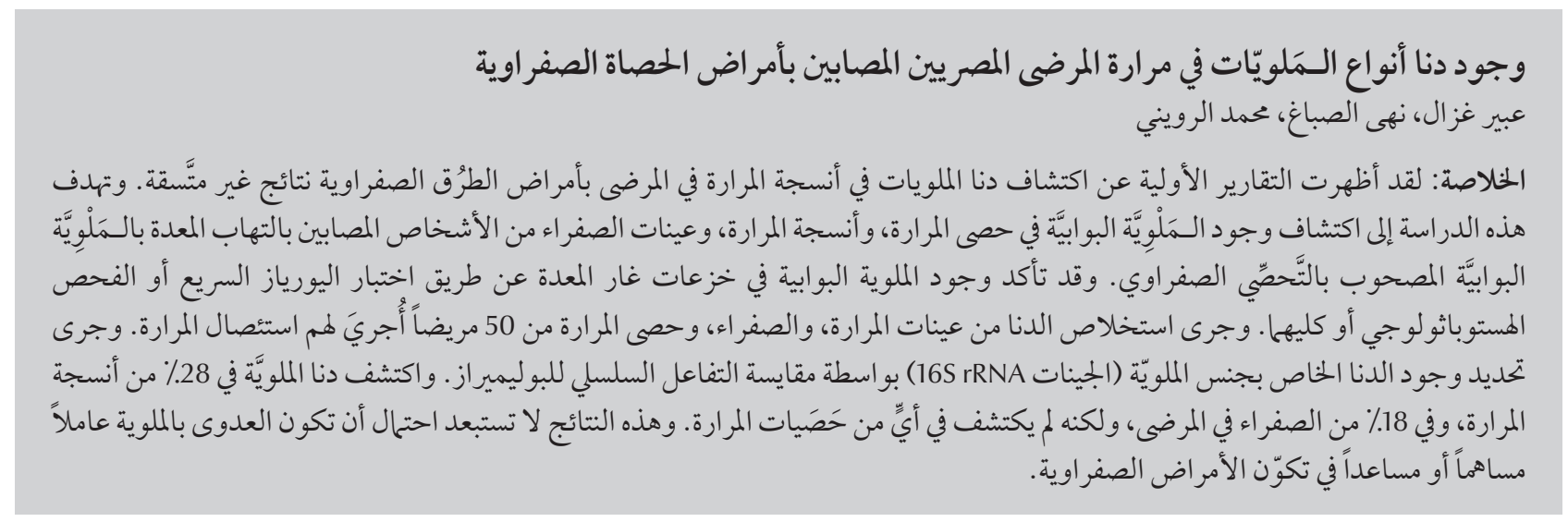

ABSTRACT Earlier reports on the detection of Helicobacter DNA in the gallbladder tissue of patients with biliary diseases have shown discordant results. This study aimed to detect the presence of Helicobacter in gallstone, gallbladder tissue and bile specimens from subjects with $H$. pylori-positive gastritis with cholelithiasis. The presence of $H$. pylori in antrum biopsies was confirmed by rapid urease test and/or histopathological examination. DNA was extracted from gallbladder, bile and gallstone samples from 50 patients undergoing cholecystectomy. The presence of Helicobacter genus-specific DNA (16S rRNA genes) was determined by nested polymerase chain reaction assay. Helicobacter DNA was detected in the gallbladder tissue and bile of $28 \%$ and $18 \%$ respectively of the patients, but was not detected in any of the gallstones. These results do not rule out the possibility of Helicobacter infection as a contributing agent or cofactor in the development of biliary diseases.

Présence d'ADN d'Helicobacter spp. dans la vésicule biliaire de patients égyptiens porteurs de calculs biliaires

RÉSUMÉ De précédentes études sur la détection d'ADN d'Helicobacter dans les tissus de la vésicule biliaire de patients porteurs de calculs ont produit des résultats discordants. L'étude visait à détecter la présence d'Helicobacter dans les échantillons de calcul, de tissu de la vésicule biliaire et de bile prélevés chez des sujets atteints d'une gastrite à $H$. pylori associée à une lithiase biliaire. La présence d'H. pylori dans les biopsies de l'antre a été confirmée par un test rapide à l'uréase et/ou un examen histopathologique. L'ADN a été extrait des échantillons de tissus de la vésicule, de bile et de calculs prélevés chez 50 patients ayant subi une cholécystectomie. La présence de I'ADN spécifique du genre Helicobacter (gènes codant l'ARN ribosomique 16S) a été déterminée au moyen de l'amplification en chaîne par polymérase nichée. L'ADN d'Helicobacter a été détecté dans les tissus de la vésicule biliaire et dans la bile de $28 \%$ et $18 \%$ respectivement des patients, mais n'était présente dans aucun des calculs. Ces résultats ne permettent pas d'éliminer la possibilité d'une infection à Helicobacter comme agent favorisant l'apparition des maladies biliaires ou comme cofacteur de leur développement. 


\section{Introduction}

The rediscovery of the bacterium in the stomach by histological examination of gastric biopsies and its first isolation by Warren and Marshall in 1983 led to new approaches to the management of various gastroduodenal disorders [1]. Its relevance to human disease, specifically to peptic ulcer disease, gastritis and gastric malignancy, is indisputable [2]. H. pylori infection has also now been implicated as a risk factor for various extraintestinal diseases and Helicobacter species have been suggested as a cause of hepatobiliary diseases in some animals [3].

Figura et al. proposed that $H$. pylori present in human bile samples might represent a risk factor for gallstoneformation [4]. These reports stimulated interest as to whether these organisms colonize the biliary tract of humans and cause hepatobiliary diseases. The evidence, however, concerning the presence of Helicobacter DNA in the bile and biliary tissue of human beings with biliary diseases is controversial [5-8]. In some studies, the presence of intestinal Helicobacter spp. or H. pylori DNA was detected in bile and or gallbladder tissue from patients with benign or malignant biliary diseases [9]. In contrast, other authors did not detect any Helicobacter DNA in the biliary trees of patients with the same diseases [10]. The role of Helicobacter in the pathogenesis of gallbladder disease in humans, or even its presence in gallbladder tissue, therefore remains unclear. The objective of this study was to investigate the presence of Helicobacter in the gallbladder, bile and gallstones of a group of Egyptian patients with $H$. pylori-positive gastritis with cholelithiasis who had undergone cholecystectomy.

\section{Methods}

\section{Patients}

A total of 50 patients with gallbladder stones admitted to University of Alexandria main hospital for cholecystectomy during the period November 2008 to June 2010 were included in this study. All patients were off any antiulcer therapy and antimicrobial drugs for at least 2 weeks before enrolment in the study. Patients with chronic pancreatitis, inflammatory bowel disease, liver cirrhosis, underlying malignancy or familial hypercholesterolaemia were excluded from the study. The study was approved by the ethics committee of each institution, and informed consent was obtained from all patients.

\section{Data collection}

\section{Clinical studies}

All patients received diagnostic upper gastrointestinal endoscopy and gastric biopsies were taken to confirm the bacterial etiology of the gastritis. Two biopsies were taken from the antrum to detect H. pylori, one for the rapid urease test [11] and the other for histopathological examination. Biopsies for histology were immediately fixed in $10 \%$ buffered formalin. The samples were then embedded in paraffin wax and histological sections were stained with haematoxylin and eosin for histological analysis.

\section{Molecular studies}

Gallbladder tissue specimens, gallstone and bile samples were obtained from each patient after cholecystectomy. The samples were immediately frozen at $-20^{\circ} \mathrm{C}$ for DNA extraction.

Extraction from gallstones [12]: DNA was extracted with a QIAamp DNA mini kit (Qiagen) according to the manufacturer's recommendations, with minor modifications. After washing with phosphate-buffered saline, each gallstone was cut into small pieces by scraping into a clean culture dish. Then $25-30 \mathrm{mg}$ was put in $1.5 \mathrm{~mL}$ Eppendorf tubes and $200 \mathrm{~mL}$ sterile digestive buffer $[20 \mathrm{mM}$ Tris- $\mathrm{HCl}$, EDTA- $\mathrm{Na}_{2}(\mathrm{pH}$ 8.0), 2 mM; 1.2\% Triton X100], was added to each tube. The content of the tubes was homogenized using a sterile plastic syringe, then $7 \mu \mathrm{L}$ lysozyme $(50 \mathrm{mg} / \mathrm{mL})$ was added to each tube and incubated at $37^{\circ} \mathrm{C}$ for 1 $\mathrm{h}$, this was followed by the addition of $200 \mu \mathrm{L}$ of ATL buffer and $20 \mu \mathrm{L}$ proteinase $\mathrm{K}(20 \mathrm{mg} / \mathrm{mL})$ and incubated at $56{ }^{\circ} \mathrm{C}$ overnight. To each sample, $200 \mu \mathrm{L}$ of AL buffer were added and the samples were centrifuged at 8000 $\mathrm{rpm}$ for $10 \mathrm{~min}$. The supernatant was transferred to a new sterile Eppendorf tube and the pellets were resuspended in $100 \mu \mathrm{L}$ of AL buffer, vortexed and centrifuged as before. The combined supernatants were incubated at $70{ }^{\circ} \mathrm{C}$ for $10 \mathrm{~min}$ then $300 \mu \mathrm{L}$ ethanol were added and the samples was applied to the QIAamp spin column in a 2 $\mathrm{mL}$ collection tube were processed according to Qiagen protocol. Finally, the DNA was eluted with $50 \mu \mathrm{L}$ of AE buffer.

Extraction from gallbladder tissue or bile [13]: $25 \mathrm{mg}$ samples of gallbladder mucosa were washed with phosphate-buffered saline and $500 \mu \mathrm{L}$ samples of refrigerated bile were pelleted by centrifugation for 10 minutes at $14000 \mathrm{rpm}$. Gallbladder tissue or bile sediments were then suspended in $180 \mu \mathrm{L}$ of lysis buffer (ATL buffer) and homogenized by vortexing, and the samples were processed according to Qiagen protocol but the column material was washed twice $(250 \mu \mathrm{L}$ each time) with the first buffer (AW1 buffer) and twice ( $250 \mu \mathrm{L}$ each time) with the second washing buffer (AW2 buffer) provided in the kit.

\section{B-PCR amplification}

B-PCR amplification was done using Helicobacter genus-specific primers [13]. The 16S rRNA gene of the genus Helicobacter was amplified by a nested polymerase chain reaction (PCR) assay. The outer primer pair (B37 and C70) was used to generate $16 \mathrm{~S}$ rRNA amplicons of approximately $1500 \mathrm{bp}$. The nested inner primer pairs, which are specific for the Helicobacter genus, amplified fragments of $400 \mathrm{bp}$ (primer pair C97 and C98). Table 1 shows the 
nucleotide sequences of the 4 primers, the PCR conditions, and the size of the amplified fragments. Ten $\mu \mathrm{L}$ of eluted DNA was used with the outer primer (C70/B37) in the first amplification. In the second round, $5 \mu \mathrm{L}$ of the PCR product was added to the reaction mixture using the nested inner primer pairs (C97/C98). PCRs were performed in a total volume of $50 \mu \mathrm{L}$ using $2 \times$ PCR master mix (Qiagen) containing 0.05 units/mL of Taq DNA polymerase, PCR buffer, $2 \mathrm{mM} \mathrm{MgCl}, 0.2 \mathrm{mM}$ of dNTPs, with 50 pmole of each primer. A negative control was included in the reaction using sterile distilled water instead of DNA to exclude the possibility of contamination. PCR products were analysed by electrophoresis using $1.5 \%(\mathrm{w} / \mathrm{v})$ agarose gel stained with ethidium bromide. The sizes of the PCR products were estimated by comparison with 100 bp DNA size markers (Fermentas).

\section{Results}

A total of 50 patients diagnosed with gastritis presenting with gallbladder stones to the Alexandria University hospital were enrolled in this study. They were 36 females (72\%) and 14 (28\%) males with ages ranging from 24-68 years, mean age 42.6 (SD 12.6) years.

Histological examination of antrum tissue specimens showed that 42 (84\%) were positive for $H$. pylori, while the rapid urease test gave positive results in $34(68 \%)$ of cases (Table 2). H. pylori was confirmed by both tests in 26 (52\%) cases. However, the urease test was negative in $16(32 \%)$ cases that were histologically positive for $H$. pylori and the urease test was positive in 8 (16\%) cases that were histologically negative for H. pylori.

Helicobacter DNA was detected by nested PCR in the gallbladder tissue and bile from 14 (28\%) and 9 (18\%) patients respectively (Table 3 and Figure 1). PCR was positive in both gallbladder tissue and bile in $6(12 \%)$ patients, while PCR was positive in gallbladder tissue only in $8(6 \%)$ cases and was only positive in bile in $3(6 \%)$ cases. No gallstones (0\%) were positive for Helicobacter DNA by nested PCR.

\section{Discussion}

The presence of Helicobacter spp./H. pylori DNA in the gallbladder epithelium of patients with cholelithiasis and cholecystitis has been addressed by several investigators. However, the results are conflicting and some investigators have detected the presence of H. pylori DNA [13] while others have not $[8,14]$. Accordingly, whether H. pylori participates in the pathogenesis of biliary diseases is a question that remains unresolved. For this reason, the presence of Helicobacter DNA in gallbladder tissue, gallstone and bile from 50 patients with cholelithiasis who had undergone cholecystectomy was investigated by nested-PCR assay using the $16 \mathrm{~S}$ rRNA gene of the genus Helicobacter.

In this study, Helicobacter DNA was detected in the gallbladder mucosa in $28 \%$ of patients with cholelithiasis. This figure agrees with 2 other studies identifying DNA of Helicobacter spp. in $22 \%-27.7 \%$ of gallbladder samples $[15,16]$. While Silva et al. detected Helicobacter DNA in gallbladder tissue in $31.3 \%$ of their cases, they pointed out the possibility that $H$. pylori had

\begin{tabular}{|c|c|c|c|}
\hline Primer [12] & Sequence $\left(5^{\prime}-3^{\prime}\right)$ & Amplicon size (bp) & PCR programme \\
\hline \multicolumn{4}{|l|}{ Outer primers } \\
\hline Forward (C70) & $\begin{array}{l}\text { AGAGTTTGATYMTGGC } \\
\text { TACGGYTACCTTGTTACGA }\end{array}$ & 1500 & $\begin{array}{l}\text { Initial denaturation for } 5 \text { min. } \\
\text { at } 94^{\circ} \mathrm{C} \text {, followed by } 25 \text { cycles } \\
\text { of (denaturation at } 94^{\circ} \mathrm{C} \text { for } \\
45 \mathrm{~s} \text {, annealing at } 50^{\circ} \mathrm{C} \text { for } 45 \\
\mathrm{~s} \text {, with final extension at } 72{ }^{\circ} \mathrm{C} \\
\text { for } 3 \text { min.), followed by } 1 \text { cycle } \\
\text { of final extension at } 72^{\circ} \mathrm{C} \text { for } \\
5 \text { min. }\end{array}$ \\
\hline \multicolumn{4}{|l|}{ Inner primers } \\
\hline Forward (C97) & GCTATGACGGGTATCC & 400 & $\begin{array}{l}\text { Initial denaturation for } 5 \text { min. } \\
\text { at } 94^{\circ} \mathrm{C} \text {, followed by } 34 \text { cycles } \\
\text { of (denaturation at } 94{ }^{\circ} \mathrm{C} \text { for } \\
1 \text { min., } 55^{\circ} \mathrm{C} \text { for } 2 \text { min., with } \\
\text { final extension at } 72^{\circ} \mathrm{C} \text { for } 3 \\
\text { min.), followed by } 1 \text { cycle of } \\
\text { final extension at } 72^{\circ} \mathrm{C} \text { for } 5 \\
\text { min. }\end{array}$ \\
\hline
\end{tabular}

bp = base pair 


\begin{tabular}{lccc}
\hline $\begin{array}{l}\text { Table } 2 \text { Results of histological examination and rapid urease test on antrum tissue } \\
\text { specimens in gastritis patients with cholelithiasis }(\boldsymbol{n}=\mathbf{5 0})\end{array}$ \\
\hline Rapid urease test & $\begin{array}{c}\text { Histological examination } \\
\text { Positive }\end{array}$ & $\begin{array}{c}\text { Negative } \\
\text { No. }\end{array}$ & Total \\
Positive & 26 & 8 & \\
Negative & 16 & 0 & 34 \\
Total & 42 & 8 & 16 \\
\hline
\end{tabular}

colonized a previously damaged epithelium [13]. In contrast, our rate was much lower than that of Apostolov et al., who reported positive $H$. pylori DNA in the gallbladder tissue of $73 \%$ of Ukrainian patients with cholecystitis [17], and it was much higher than Méndez-Sánchez et al., who found a very low incidence (3\%) of Helicobacter colonization in the gallbladder epithelium of a Mexican population (detected using Helicobacter-specific 16S rRNA primers) [8]. Méndez-Sánchez et al. argued that the existence of uncommon Helicobacter spp in gallbladder epithelium and its association with gallstone pathogenesis could not be discarded.

Moreover, in our study, Helicobacter DNA could be detected in the bile of $18 \%$ of patients presenting with gallbladder stones. Similar data was reported by Lee et al., who found Helicobacter

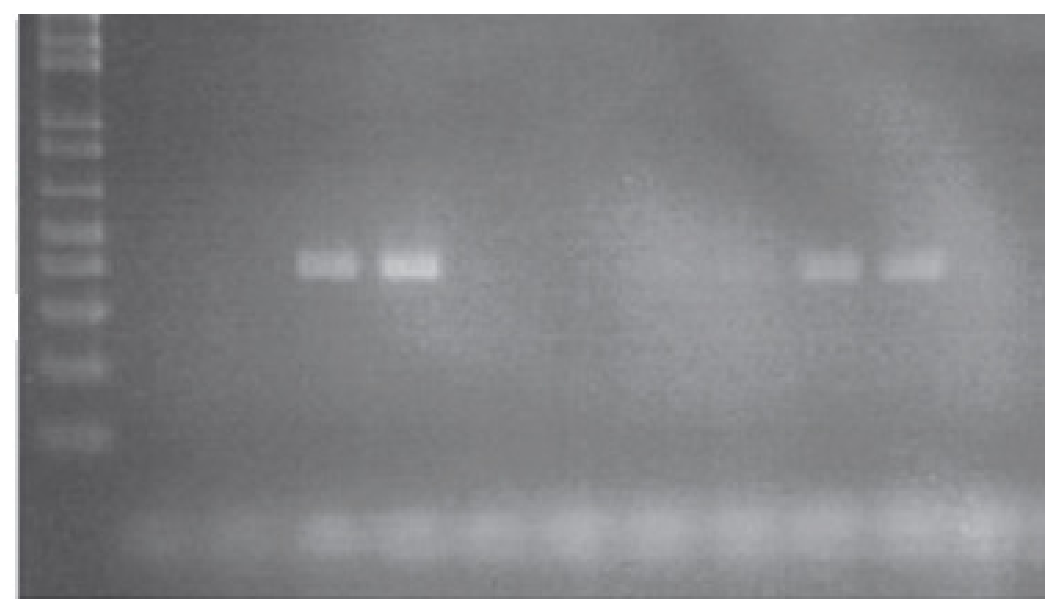

Figure 1 Ethidium bromide stained gel electrophoresis showing polymerase chain reaction products of the 400-bp fragments of the $16 \mathrm{~S}$ rRNA gene of Helicobacter spp. (lanes 4,5,10 and 11). Lane 1 represents 100-bp molecular weight marker, and lane 12 represent reaction negative control
DNA in $25 \%$ of the bile from patients with gallstones [15]. Still higher rates (42.9\% and $96.7 \%)$ were reported in the bile of patients diagnosed with various hepatobiliary diseases by other authors $[1,13]$. Fox et al. reported that bile samples from $56.5 \%$ of 23 Chilean patients with chronic cholecystitis were positive for Helicobacter spp [7]. These were analysed by DNA sequencing and were found to be bile-resistant hepatic Helicobacter spp. (H. bilis, $H$. pullorum and Flexispira rappini), known to be closely associated with gallbladder cancer. Intestinal Helicobacter spp. are bile-resistant, a property that may confer protection against the deleterious effects of bile in vivo and allow them to adapt better to the hepatobiliary surroundings [13].

In this study, the presence of Helicobacter spp. DNA in gallbladder tissue or

bile could be linked with the presence of H. pylori in the antrum. Chen et al. reported that Helicobacter spp. DNA are commonly present in the gallbladder of patients with gallstone diseases and in controls, implying that Helicobacter infection alone may not play a significant role in the formation of gallstones [18]. However their results did not exclude the possibility of Helicobacter infection as a cofactor in the development of gallstones. Also, in a German study no Helicobacter spp. were found in bile samples, suggesting that there may be racial and demographic differences in the etiology of gallstones [14].

It has been proposed that the presence of $H$. pylori in bile may represent an increased risk of gallstone formation [4]. A possible consequence of colonization by Helicobacter spp. is a chronic inflammation in the gallbladder mucosa. This inflammation may impair gallbladder mucosa acid secretion and acidification of the contents [19], reducing the solubility of calcium salts in gallbladder bile and increasing the risk of their precipitation in the lumen [20]. Helicobacter spp. were assessed by PCR in gallstones in several studies. In a study from Sweden, Monstein et al. detected H. pylori in 55\% of cholesterol gallstones, in addition to other bacteria [12]. In our study, Helicobacter could not be detected by PCR in any gallstones. However Farshad et al. reported the presence of H. pylori DNA in 18.1\% of stone samples and suggested that $H$. pylori infection may serve as an initiating factor or play other important roles in the development of gallstones [21].

The reasons for observed discrepancies in the detection rate of Helicobacter among different studies are currently unclear, but differences in PCR sensitivities between laboratories and geographical variations in human exposure to $H$. pylori are 2 possible explanations. These differences reflect the need for prospective studies using accurate tests designed to clarify the clinical role of Helicobacter 


\begin{tabular}{|c|c|c|c|}
\hline $\begin{array}{l}\text { Table } 3 \text { Results o } \\
\text { tissue and bile sa }\end{array}$ & $\begin{array}{l}\text { chain reac } \\
\text { ritis patie }\end{array}$ & $\begin{array}{l}\text { R) amplific } \\
\text { cholelithia }\end{array}$ & allbladder \\
\hline Bile PCR results & Gallbla & 2 results & Total \\
\hline & Positive & Negative & \\
\hline & No. & No. & \\
\hline Positive & 6 & 3 & 9 \\
\hline Negative & 8 & 33 & 41 \\
\hline Total & 14 & 36 & 50 \\
\hline
\end{tabular}

spp. in gallbladder disease. Also, the these studies, including ours, may be small number of patients enrolled in all a factor. Therefore larger patient and control groups are needed to ascertain whether this microorganism is an innocent bystander or active participant in gallstone formation.

In conclusion, the results of the present study revealed the presence of Helicobacter DNA in gallbladder tissue and bile from patients with gallbladder diseases. Further studies are needed to determine whether Helicobacter spp. is a causative agent of biliary diseases or a cofactor.

\section{References}

1. Tiwari SK et al. Helicobacter pylori and other Helicobacter species DNA in human bile samples from patients with various hepato-biliary diseases. World Journal of Gastroenterology, 2006, 12:2181-2186.

2. Hardin FJ, Wright RA. Helicobacter pylori: review and update. Hospital Physician, 2002, May:23-31.

3. Ward JM et al. Chronic active hepatitis in mice caused by Helicobacter hepaticus. American Journal of Pathology, 1994, 145:959-968.

4. Figura $\mathrm{N}$ et al. Most Helicobacter pylori-infected patients have specific antibodies, and some also have H. pylori antigens and genomic material in bile. Is it a risk factor for gallstone formation? Digestive Diseases and Sciences, 1998, 43:854-862.

5. Myung SJ et al. Detection of Helicobacter pylori DNA in human biliary tree and its association with hepatolithiasias. Digestive Diseases and Sciences, 2000, 45:1405-1412.

6. Roosendaal $\mathrm{R}$ et al. Helicobacter species are not detected by 16SrDNA PCR in bile from Dutch patients with common bile duct stones. Digestion, 2002, 66:89-91.

7. Fox JG et al. Hepatic Helicobacter species identified in the bile and gallbladder tissue from Chileans with chronic cholecystitis. Gastroenterology, 1998, 114:755-763.

8. Mendez-Sanchez $\mathrm{N}$ et al. Lack of association between Helicobacter sp. colonization and gallstone disease. Journal of Clinical Gastroenterology, 2001, 32:138-141.

9. Bulajic $\mathrm{M}$ et al. Helicobacter pylori and the risk of benign and malignant biliary tract disease. Cancer, 2002, 95:1946-1953.

10. Bulajic $\mathrm{M}$ et al. Modalities of testing Helicobacter pylori in patients with nonmalignant bile duct diseases. World Journal of Gastroenterology, 2002, 8:301-304.

11. Malfertheiner P et al. Modified rapid urease test for detection of Helicobacter pylori infection. European Journal of Gastroenterology and Hepatology, 1996, 8(1):53-56.
12. Jonsson Y, Zdolsek J, Svanvik J. Identification of Helicobacter pylori DNA in human cholesterol gallstones. Scandinavian Journal of Gastroenterology, 2002, 37:112-119.

13. Silva CP et al. Association of the presence of Helicobacter in gallbladder tissue with cholelithiasis and cholecystitis. Journal of Clinical Microbiology, 2003, 41:5615-5618.

14. Rudi J et al. Helicobacter sp. are not detectable in bile from German patients with biliary disease. Gastroenterology, 1999, 116:1016-1017.

15. Lee JW et al. Identification of Helicobacter pylori in gallstone, bile, and other hepatobiliary tissues of patients with cholecystitis. Gut and Liver, 2010, 4:60-67.

16. Salih BA et al. Helicobacter pylori DNA in gallbladder tissue of patients with cholelithiasis and cholecystitis. Journal of Infection in Developing Countries, 2009, 3:856-859.

17. Apostolov E et al. Helicobacter pylori and other Helicobacter species in the gallbladder and liver of patients with chronic cholecystitis detected by immunological and molecular methods. Scandinavian Journal of Gastroenterology, 2005, 40:96-102.

18. Chen DF et al. Common presence of Helicobacter DNA in the gallbladder of patients with gallstone diseases and controls. Digestive and Liver Disease, 2003, 35:237-243.

19. Nilsson B et al. Inflammation reduces mucosal secretion of hydrogen ions and impairs concentrating function and luminal acidification in feline gallbladder. Scandinavian Journal of Gastroenterology, 1995, 30:1021-1026.

20. Cetta F et al. Helicobacter pylori in the bile could play a facilitating role in the pathogenesis of some types of gallstones [Abstract]. Gastroenterology, 2000, 118(Suppl. 2):7a.

21. Farshad SH et al. Identification of Helicobacter pylori DNA in Iranian patients with gallstones. Epidemiology and Infection, 2004, 132:1185-1189. 